\title{
A stable temperature may favour continuous reproduction by Theodoxus fluviatilis and explain its high densities in some karstic springs
}

\author{
Manuel A. S. Graça*, Sónia R. Q. Serra and Verónica Ferreira \\ IMAR-CMA and Department of Life Sciences, University of Coimbra, PO Box 3046, 3001-401 Coimbra, \\ Portugal. \\ * Corresponding author: mgraca@ci.uc.pt
}

Received: 30/5/2011 Accepted: 27/12/2011

\begin{abstract}
A stable temperature may favour continuous reproduction by Theodoxus fluviatilis and explain its high densities in some karstic springs

Theodoxus fluviatilis is a common gastropod in many karstic springs in central Portugal. We investigated the possible reasons for the near-total restriction of this species to these springs. We first determined the spatial distribution of the species within a spring (Anços) and related the densities at sampling-patch scales to selected physical and chemical variables. We then determined the densities at several locations downstream from the spring and related these densities to selected physical and chemical variables. Finally, we assessed the population dynamics of the gastropod in the spring. In the spring, T. fluviatilis was more abundant in shallow areas with a rapid current and cobble-boulder substrates. In June-July 2006, the mean densities of T. fluviatilis in the spring varied from $\sim 10$ to $\sim 9000$ individuals $\mathrm{m}^{-2}$ but decreased to zero $3800 \mathrm{~m}$ downstream. The physical and chemical changes along the stretch studied were minor; no significant correlations (Spearman rank correlation; $p>0.05$ ) were observed between the gastropod abundances and the measured environmental variables or the PCA axes. In the spring, juveniles and egg masses were observed year-round, suggesting continuous reproduction. The temperature at the spring was fairly constant, ranging from 15.3 to $16.6^{\circ} \mathrm{C}$ during the year (daily variation $<0.1{ }^{\circ} \mathrm{C}$ ). Nine hundred metres farther downstream, the daily temperature variation reached $5{ }^{\circ} \mathrm{C}$. We propose that the high densities of T. fluviatilis in the Anços spring are maintained by continuous recruitment mediated by the constant high temperature.
\end{abstract}

Key words: Secondary production, substrate, population dynamics, Portugal, macroinvertebrates.

\section{RESUMEN}

La estabilidad térmica en manantiales kársticos puede favorecer la reproducción continua de Theodoxus fluviatilis, explicando así sus altas densidades

Theodoxus fluviatilis es un gasterópodo común en muchas de los manantiales kársticos del centro de Portugal. La pregunta a la que intentamos responder es ¿por qué la especie está prácticamente restricta a los manantiales? Para ello determinamos primero la distribución espacial de T. fluviatilis en el manantial calcáreo del río de Anços y relacionamos la densidad a nivel de hábitats del tramo con algunos parámetros fisicoquímicos. Posteriormente determinamos densidades en varios puntos río abajo y las relacionamos con las condiciones químicas y físicas. Finalmente, determinamos la dinámica de poblaciones en el manantial. En el manantial kárstico T. fluviatilis fue más abundante en las zonas poco profundas con corriente y substrato pedregosos. En Junio-Julio de 2006, las densidades medias de T. fluviatilis variaron entre $\sim 10$ y 9000 individuos $\mathrm{m}^{-2}$ en el manatial, pero bajaron a cero 3800 m río abajo. Los cambios fisicoquímicos a los 3800 m fueron mínimos; no fueron observadas correlaciones significativas (correlación de rangos de Spearman, $\mathrm{p}>0.05$ ) entre la abundancia de T. fluviatilis y las variables ambientales o los ejes de Análisis de Componentes Principales. En el manantial, juveniles y masas de huevos fueron observadas durante todo el año y no se obsevaron cohortes, sugeriendo reproducción contínua. La temperatura en el manantial varió entre 15.3 y $16.6^{\circ} \mathrm{C}$ durante todo el año (variación diaria $<0.1{ }^{\circ} \mathrm{C}$ ). Novecientos metros río abajo las variaciones térmicas diarias llegaron a los $5^{\circ} \mathrm{C}$. Proponemos pues que la elevada densidad de T. fluviatilis en el manantial kárstico de Anços se mantiene gracias a las temperaturas elevadas y constantes que favorecen su continua reproducción.

Palabras clave: Producción secundaria, sustratos, dinámica de poblaciones, Portugal, macroinvertebrados. 


\section{INTRODUCTION}

Theodoxus fluviatilis (Linnaeus, 1758) is a freshwater gastropod occurring throughout Europe and Anatolia in lakes, streams, rivers, canals and even estuaries and brackish waters up to $60 \mathrm{~m}$ in depth (Fretter \& Graham, 1978; Zettler et al., 2004; Bunje, 2005; Kirkegaard, 2006; Bunje \& Lindberg, 2007). These gastropods are occasionally numerous, particularly in clean waters with a high calcium content (Carlsson, 2000), where they feed on biofilms, ingesting mainly diatoms, but also feed on blue-green algae and detritus (Fretter \& Graham, 1978; Zettler et al., 2004; Kirkegaard, 2006). The life-history of T. fluviatilis is little known despite the species' wide distribution. Reproduction, embryo development and egg hatching have been reported to occur at temperatures above $10-12^{\circ} \mathrm{C}$ (Fretter \& Graham, 1978; Kirkegaard, 2006). Embryo development has been reported to last for 30 days at $25^{\circ} \mathrm{C}$ and for 65 days at $20^{\circ} \mathrm{C}$ (Kirkegaard, 2006). Temperature also affects development, survivorship and seasonal density variation (Kirkegaard, 2006). To our knowledge, all previous studies of this gastropod have been conducted in temperate seasonal systems. We observed that $T$. fluviatilis was abundant in and almost entirely restricted to many karstic springs in central Portugal. However, its densities decreased rapidly downstream. To our knowledge, the reason for this distribution in central Portugal and in other locations has not yet been addressed, but other authors have also found high densities of T. fluviatilis in some karstic springs (e.g., Barquín and Death, 2009). Most likely, the distribution is related to changes in water chemistry (decreases in alkalinity and calcium content and changes in dissolved gases), physical variables (variability of water temperatures, current and availability of appropriate substrates), the quality of food resources, or the presence of competitors or predators.

These (and other) factors surely play an important role in the structuring of macroinvertebrate assemblages, as suggested by numerous studies showing that springs have very different macroinvertebrate communities compared with the streams flowing from the springs (Barquín \&
Death, 2004, 2006). Whereas insects generally predominate in streams, karstic springs are generally dominated by invertebrates with high calcium requirements, such as crustaceans (amphipods, isopods) and gastropods (Barquín \& Death, 2004).

Our main aim was to determine the reasons for the decreased densities of T. fluviatilis downstream from the springs. Therefore, we first investigated density variations within a karstic spring. We then quantified changes in densities of T. fluviatilis downstream from the spring in relation to changes in the environmental conditions. Given the importance of $\mathrm{CaCO}_{3}$ for shell building (Dahm et al., 1998; Allan \& Castillo, 2007), our hypothesis was that alkalinity was the main driver of the abundance of this species. Third, given the high thermal stability of springs, we hypothesised that life-history parameters would be little affected by yearly temperature-related events and that reproduction should therefore occur year-round.

\section{MATERIALS AND METHODS}

\section{Study area}

Our study was conducted at the spring source of the Anços River (Olhos de Água; N 39 $58^{\prime} 43^{\prime \prime}$, W $08^{\circ} 34^{\prime} 21^{\prime \prime} ; 69 \mathrm{~m}$ asl), which is fed by two major groundwater outlets and has a mean yearly flow of $50000 \mathrm{~m}^{3}$ (Cunha, 1990). The spring is bordered essentially by Salix spp. and Populus spp. and is located in an agricultural area. The streambed downstream from the spring includes stony, sandy and muddy areas where Apium nodiflorum thrives. The area of the spring is $\sim 20 \times 12 \mathrm{~m}$, and the width of the river ranges from $\sim 15 \mathrm{~m}$ just outside of the spring to $\sim 30 \mathrm{~m}$ at its widest portion in the study area.

\section{Spatial distribution}

To understand the spatial distribution of $T$. $f u$ viatilis, i.e., if the species is associated with a particular type of substrate and other conditions such as depth and current velocity, we randomly collected 31 Surber samples $(0.3 \times 0.3 \mathrm{~m}$ 
opening and $0.5 \mathrm{~mm}$ mesh size) from the spring in December 2005. The samples were distributed across three distinct areas: (A) the upstream outlets of the groundwater, which feed a small pond $(n=9)$; (B) a very wide area farther downstream, where macrophytes usually grow $(n=20)$; and (C) lateral smaller outlets discharging into the wide area $(n=3)$. At each sampling point (Surber), we assessed the depth, current (VALEPORT 15277), the dominant substrate size (boulder: > $256 \mathrm{~mm}$; cobble: 64-256 mm; pebble/gravel: 2-64 mm; sand: 0.06-2 mm; and silt $<0.06 \mathrm{~mm}$ ) and the presence of macrophytes. We also measured the temperature, $\mathrm{pH}$, electrical conductivity and dissolved oxygen with field probes. The biological samples were preserved in $4 \%$ formalin (neutralised with sodium tetraborate) and transported to the laboratory. In the laboratory, the samples were washed with running tap water over a column of sieves $(0.5,1$ and $2 \mathrm{~mm}$ ), and the specimens of $T$. fluviatilis were sorted and counted.

\section{Longitudinal distribution}

We investigated the occurrence of the population of $T$. fluviatilis at different distances beyond the spring, and we determined the relationship between these population densities and changes in the physical and chemical conditions. Three Surber samples were taken at 0, 25, 100, 200, 800, 1000, 1800 and $3800 \mathrm{~m}$ downstream from the spring in three different habitats (macrophytes, stony and sandy substrates) in June and July 2006 and processed as described above. Simultaneously, we measured the physical and chemical variables listed above and the type of flow (riffle, run, pool). We also took one L of water in a clean plastic bottle for ion determinations $\left(\mathrm{F}^{-}, \mathrm{CH}_{3} \mathrm{CO}_{2}, \mathrm{Cl}^{-}, \mathrm{NO}_{2}^{-}, \mathrm{NO}_{3}^{-}, \mathrm{SO}_{4}^{2-}, \mathrm{Na}^{+}, \mathrm{NH}_{4}^{+}\right.$, $\mathrm{K}^{+}, \mathrm{Mg}^{2+}, \mathrm{Ca}^{2+}$; ion chromatograph, Dionex DX120 , Sunnyvale, CA). Soluble reactive phosphorus (SRP) was determined by the ascorbic acid method and alkalinity was determined by titration with $\mathrm{H}_{2} \mathrm{SO}_{4}$ to a final $\mathrm{pH}$ of 4.5 (APHA, 1995).

\section{Population dynamics}

In karstic springs, thermal conditions tend to be buffered against seasonal variations during the year. Because reproduction in invertebrates depends strongly on temperature, we hypothesised that in such environments, seasonality in reproduction should be less apparent. To test this hypothesis, we sampled the population monthly from June 2006 to June 2007 in three habitats: macrophyte beds, stony substrates and sandy substrates. Samples were taken with a hand net $(0.25 \times 0.25 \mathrm{~m}$ and $0.5 \mathrm{~mm}$ mesh size $)$ covering an area comparable to the Surber sampler $(0.3$ $\times 0.3 \mathrm{~m}$ ). Stones were placed in a bucket and washed with a brush. In the laboratory, the shell length (L) of each individual was measured to $\pm 0.1 \mathrm{~mm}$ to allow the calculation of individual biomass (B, as ash-free dry mass-AFDM in $\mathrm{mg}$; $B=0.17 e^{0.5361 * L}, R^{2}=0.80 ; p<0.001$; length ranged from 1.4 to $10.6 \mathrm{~mm}$ ).

\section{Data treatment}

\section{Spatial distribution}

To understand which variables best explained the distribution of $T$. fluviatilis, we performed a principal components analysis (PCA) on the environmental variables $\mathrm{pH}$, temperature, dissolved oxygen, electrical conductivity, current velocity, depth and substrate type (normalised; PRIMER 6). The densities of T. fluviatilis were $\log (x+1)$ transformed and regressed against PCA axes 1 and 2. A multiple regression analysis (backwards; STATISTICA 6) was also used to investigate the importance of each environmental variable for the numbers of $T$. fluviatilis $(\log (x+1))$. Finally, to assess the importance of substrate in the distribution of $T$. fluviatilis, we compared the abundance of the species in three habitats (stony substrates, sandy substrates and macrophyte beds) in spring area B by an ANOVA. To guarantee the normal distribution of data and the homogeneity of variances, we used a 
Shapiro-Wilk W test (STATISTICA 6) and a Bartlett Chi-Squared test (STATISTICA 6).

\section{Longitudinal distribution}

The abundance data were subjected to a two-way analysis of variance (2-way ANOVA), with distance to the source and habitat type as factors (STATISTICA 6). The environmental data were again subjected to a PCA and the density data were regressed against PCA axes 1 and 2 (PRIMER 6).

\section{Population dynamics}

Population dynamics was analysed in terms of biomass $(\mathrm{B}$, in $\mathrm{mg})$. The densities $(\log (x+1))$ were higher in stony substrates than in sand and macrophytes (2-way ANOVA) and we therefore further investigated changes in densities $(\log (x+1))$ and biomass only in stony substrates across the year with a 1-way ANOVA (STATISTICA 6), with time as a factor. The growth rates and secondary production were subjected to a modal analysis in ANAMOD software (Nogueira, 1992). Because no cohorts were identified, we calculated secondary production from July 2006 to June 2007 by the Hynes size-frequency method, according to Krueger and Martin (1980), in which the annual production $(\mathrm{P})$ is given by:

$$
P=\left\{i \sum_{j=1}^{i}\left(\bar{n}_{j}-\bar{n}_{j+1}\right) \cdot\left(W_{j} \cdot W_{j+1}\right)^{\frac{1}{2}}\right\} \cdot \frac{365}{\mathrm{CPI}}
$$

in which $i$ is the number of size classes, $n_{j}$ is the number of individuals reaching a particular size $j$ in one year, $W_{j}$ is the mean individual biomass in size $j$ and CPI (cohort production interval) is the mean number of days that an individual in a cohort takes to reach the maximum size (3.5 years * 365 days; Kirkegaard, 2006). We then calculated $P / B$. We recognise that the CPI in Kirkegaard (2006) was determined for a different environment, in which the temperatures were lower than those reported in Anços spring. In this warmer environment, it is predictable that $T$. fluviatilis would have shorter life cycles. Therefore, the real CPI would be lower than that determined from the study of Esrom Lake by Kirkegaard (2006) and the production estimate should be considered a minimum value.

\section{RESULTS}

\section{Spatial distribution}

The three spring locations, A, B and C, did not differ markedly in most of their environmental variables (Table 1). Nevertheless, they were segregated by PCA, with axes 1 and 2 explaining 32 and $23 \%$ of the variation, respectively (Fig. 1). The abundance of $T$. fluviatilis was negatively correlated with PCA axis 2 according to the equation

$$
\begin{aligned}
& \log (\text { Abundance }+1)= \\
& \quad=-0.48 \times(\text { PCA2 })+1.05( \pm 0.12) \\
& R^{2}=0.59 ; p<0.001 ; n=26 .
\end{aligned}
$$

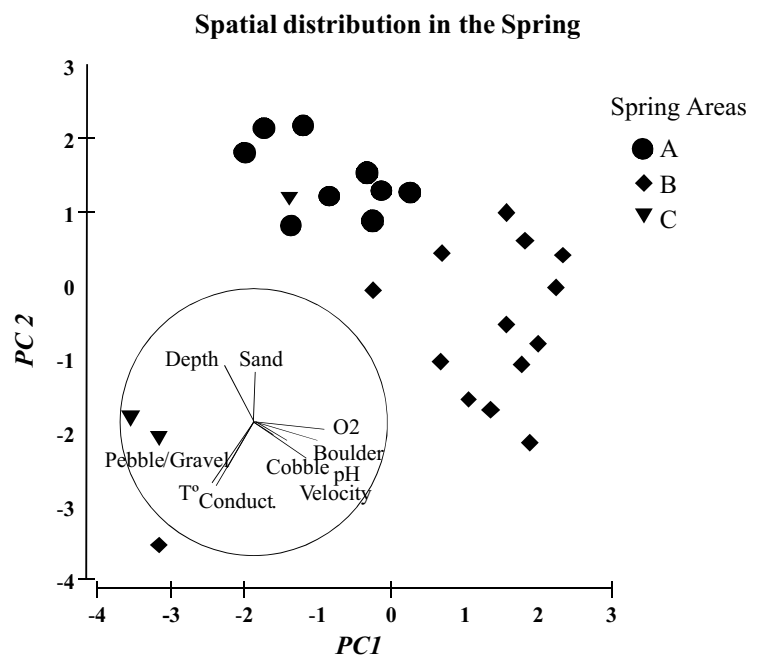

Figure 1. Principal Components Analysis of 26 samples $\times 10$ environmental variables for Anços spring. Environmental variables: $\mathrm{pH}$, temperature, dissolved oxygen, electrical conductivity, current velocity, depth and substrate type (according to their predominance) at several locations within the spring (see Table 1 for locations A, B and C). Axes 1 and 2 explained $32 \%$ and $23 \%$, respectively, of the variation. Análisis de Componentes Principales de 26 muestras $\times 10$ variables ambientales en el manantial del río Anços: $p H$, temperatura, oxígeno disuelto, conductividad eléctrica, velocidad de la corriente, profundidad, y tipo de sustrato (de acuerdo con su predominancia) en varios puntos dentro del manantial (ver Tabla 1 para puntos $A, B, y C)$. Ejes 1 y 2 explicaran $32 \%$ y $23 \%$ de la variación. 
Table 1. Physical and chemical variables measured in situ in an upstream sector of the spring (A), lateral entrances of groundwater (C) and the large lower section where the waters meet (B). Mean ( $\pm 1 \mathrm{SE})$ [minimum; maximum]; $n=23$. Variables fisicoquimicas medidas in situ aguas arriba del manantial (A), entradas laterales de aguas subterráneas (C), y aguas abajo donde confluyen las aguas de los puntos anteriores (B). Media y Error Estándar ( \pm 1 SE) [mínimo; máximo]; $\mathrm{n}=23$.

\begin{tabular}{|c|c|c|c|}
\hline \multirow{2}{*}{$\begin{array}{l}\text { Physical and } \\
\text { chemical variables }\end{array}$} & \multicolumn{3}{|c|}{ Spring Areas } \\
\hline & Upstream (A) & Downstream (B) & Lateral (C) \\
\hline $\mathrm{pH}$ & $\begin{array}{c}7.1( \pm 0.1) \\
{[6.9 ; 7.2]}\end{array}$ & $\begin{array}{c}7.2( \pm 0.1) \\
{[7.0 ; 7.4]}\end{array}$ & $\begin{array}{c}7.1( \pm 0.1) \\
{[7.0 ; 7.1]}\end{array}$ \\
\hline Temperature $\left({ }^{\circ} \mathrm{C}\right)$ & $\begin{array}{l}16.0( \pm 0.1) \\
{[15.9 ; 16.1]}\end{array}$ & $\begin{array}{l}16.1( \pm 0.1) \\
{[16.0 ; 16.5]}\end{array}$ & $\begin{array}{l}16.3( \pm 0.3) \\
{[16.0 ; 16.5]}\end{array}$ \\
\hline Oxygen saturation (\%) & $\begin{array}{c}105( \pm 2) \\
{[102 ; 108]}\end{array}$ & $\begin{array}{c}112( \pm 3) \\
{[105 ; 114]}\end{array}$ & $101( \pm 0.00)$ \\
\hline Dissolved oxygen $\left(\mathrm{mg} \mathrm{l}^{-1}\right)$ & $\begin{array}{l}10.3( \pm 0.2) \\
{[10.1 ; 10.6]}\end{array}$ & $\begin{array}{l}10.9( \pm 0.3) \\
{[10.0 ; 11.2]}\end{array}$ & $9.9( \pm 0.00)$ \\
\hline Conductivity $\left(\mu \mathrm{S} \mathrm{cm}^{-1}\right)$ & $483( \pm 0.00)$ & $\begin{array}{l}487( \pm 5) \\
{[485 ; 504]}\end{array}$ & $\begin{array}{l}500( \pm 12) \\
{[486 ; 507]}\end{array}$ \\
\hline Velocity $\left(\mathrm{m} \mathrm{s}^{-1}\right)$ & $\begin{array}{c}0.4( \pm 0.3) \\
{[0.1 ; 0.9]}\end{array}$ & $\begin{array}{c}1.3( \pm 0.6) \\
{[0.3 ; 2.7]}\end{array}$ & $\begin{array}{c}0.3( \pm 0.2) \\
{[0.0 ; 0.5]}\end{array}$ \\
\hline Depth $(\mathrm{cm})$ & $\begin{array}{c}52( \pm 15.3) \\
{[40 ; 85]}\end{array}$ & $\begin{array}{c}22( \pm 6.8) \\
{[12 ; 36]}\end{array}$ & $\begin{array}{c}31( \pm 5.5) \\
{[25 ; 35]}\end{array}$ \\
\hline Boulder substrate (\%) & $\begin{array}{c}16( \pm 33) \\
{[0 ; 100]}\end{array}$ & $\begin{array}{c}32( \pm 36) \\
{[0 ; 90]}\end{array}$ & $\begin{array}{c}33( \pm 12) \\
{[20 ; 40]}\end{array}$ \\
\hline Cobble substrate $(\%)$ & $\begin{array}{c}7( \pm 12.5) \\
{[0 ; 40]}\end{array}$ & $\begin{array}{c}8( \pm 9.6) \\
{[0 ; 30]}\end{array}$ & $0( \pm 0.0)$ \\
\hline Pebble substrate (\%) & $\begin{array}{c}19( \pm 22) \\
{[0 ; 60]}\end{array}$ & $\begin{array}{c}22( \pm 28) \\
{[0 ; 90]}\end{array}$ & $\begin{array}{c}28( \pm 18) \\
{[10 ; 45]}\end{array}$ \\
\hline Sandy substrate (\%) & $\begin{array}{c}26( \pm 31) \\
{[0 ; 80]}\end{array}$ & $\begin{array}{c}21( \pm 34) \\
{[0 ; 100]}\end{array}$ & $\begin{array}{c}35( \pm 15) \\
{[20 ; 50]}\end{array}$ \\
\hline
\end{tabular}

This equation suggests that high current velocity, a substrate larger than sand, high electrical conductivity, shallow areas and high temperature were all important factors affecting the numbers of T. fluviatilis. Indeed, the numbers of specimens were explained (multiple regression analysis) by three factors: the substrate type (with predominance of boulders or cobbles), depth and electrical conductivity by the equation:

$\log ($ Abundance +1$)=$

$$
\begin{aligned}
& =0.02 \times \text { boulders }-0.034 \times \text { depth }+ \\
& +0.048 \times \text { conductivity }+0.03 \times \text { cobbles }- \\
& -21.84( \pm 0.378) \\
R^{2} & =0.86 ; p<0.001 ; n=26
\end{aligned}
$$

The samples of $T$. fluviatilis in the wide B area of the spring were taken in three different habitat types: stony substrates, sandy substrates and macrophyte beds. The densities of $T$. fluviatilis in sandy substrates (monthly average) reached 100 individuals $\mathrm{m}^{-2}$; this value was 2.5 times higher in macrophyte beds (250) and almost 100fold higher in stony substrates (8300; ANOVA by ranks; $H=13.814 ; p<0.001$; Fig. 2).

\section{Longitudinal distribution}

The densities of $T$. fluviatilis were highest at the spring and $200 \mathrm{~m}$ downstream. They then decreased longitudinally. At $3800 \mathrm{~m}$ downstream, 


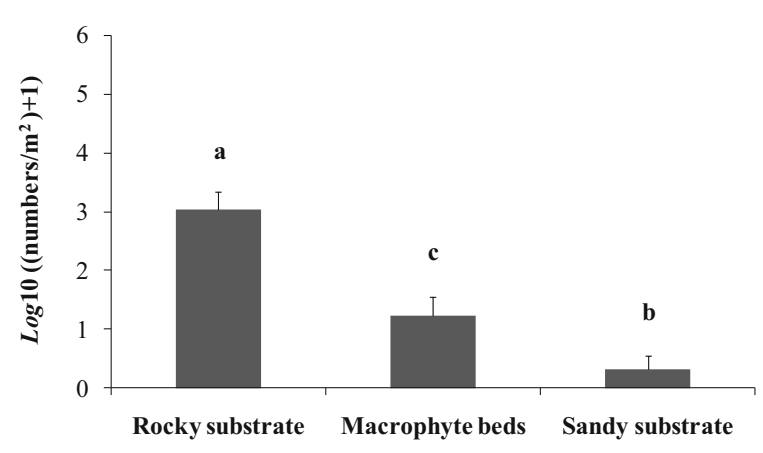

Figure 2. Theodoxus fluviatilis abundances across three substrate types sampled in the Anços spring in June and July 2006. ANOVA by ranks $(n=18)$; different letters denote significant differences according to a post-hoc (Tukey) test. Mean \pm 1 SE. Abundancia de Theodoxus fluviatilis en tres tipos de sustrato muestreados en el manantial del río Anços en junio y julio de 2006. ANOVA por rangos $(\mathrm{n}=18)$; las distintas letras denotan diferencias significativas de acuerdo con un test post-hoc (Tuckey). Media $\pm 1 S E$.

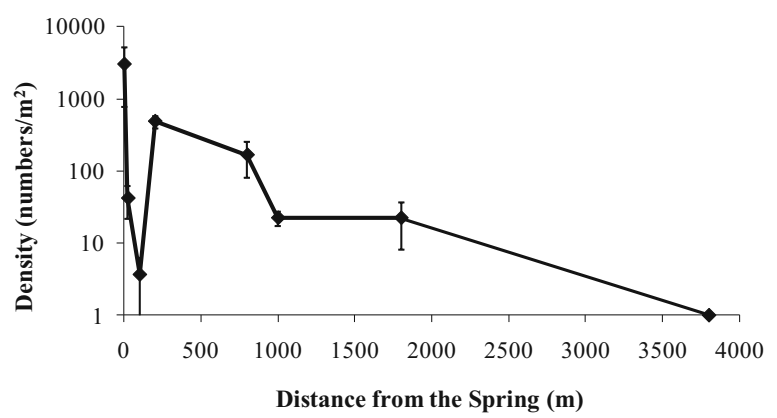

Figure 3. Longitudinal distribution of Theodoxus fluviatilis along the Anços River. Mean \pm 1 SE. Distribución longitudinal de Theodoxus fluviatilis a lo largo se un sector del río Anços. Media $\pm 1 S E$.

we found no specimens of $T$. fluviatilis in the samples (Fig. 3). Oxygen, $\mathrm{Na}^{+}, \mathrm{K}^{+}$and $\mathrm{Cl}^{-}$ tended to increase downstream (Table 2). The two main axes of the PCA on the abiotic factors

Table 2. Theodoxus fluviatilis mean abundance and physical and chemical variables measured at the Anços spring and downstream. Abundancias medias de Theodoxus fluviatilis y variables fisicoquímicas medidas en el manantial del río Anços y tramos aguas abajo.

\begin{tabular}{|c|c|c|c|c|c|c|c|c|}
\hline & \multicolumn{8}{|c|}{ Distance to the spring source (m) } \\
\hline & $\mathbf{0}$ & 25 & 100 & 200 & 800 & 1000 & 1800 & 3800 \\
\hline Mean abundance of Theodoxus $\left(\mathrm{m}^{-2}\right)$ & 3002 & 41 & 3 & 485 & 331 & 21 & 21 & 0 \\
\hline $\mathrm{pH}$ & 6.9 & 7.0 & 7.5 & 7.6 & 7.5 & 7.6 & 7.9 & 7.9 \\
\hline Conductivity $\left(\mu \mathrm{S} \mathrm{cm}^{-1}\right)$ & 493 & 491 & 491 & 486 & 487 & 485 & 493 & 491 \\
\hline Temperature $\left({ }^{\circ} \mathrm{C}\right)$ & 16.3 & 16.7 & 16.9 & 17.4 & 18.0 & 18.0 & 17.6 & 19.4 \\
\hline Dissolved oxygen $\left(\mathrm{mg} \mathrm{l}^{-1}\right)$ & 9.1 & 9.4 & 9.6 & 9.6 & 9.1 & 9.1 & 9.1 & 10.0 \\
\hline Depth $(\mathrm{cm})$ & 18 & 51 & 78 & 73 & 46 & 40 & 29 & 73 \\
\hline Macrophyte habitat (\%) & 30 & 70 & 100 & 100 & 100 & 100 & 100 & 0 \\
\hline Stony substrate (\%) & 30 & 20 & 0 & 0 & 0 & 0 & 0 & 0 \\
\hline Sandy substrate (\%) & 40 & 10 & 0 & 0 & 0 & 0 & 0 & 100 \\
\hline Riffle $(\%)$ & 5 & 0 & 0 & 0 & 0 & 0 & 0 & 0 \\
\hline Run $(\%)$ & 90 & 60 & 70 & 25 & 15 & 30 & 100 & 5 \\
\hline Pool $(\%)$ & 5 & 40 & 30 & 75 & 85 & 70 & 0 & 95 \\
\hline $\mathrm{Na}^{+}\left(\mathrm{mg} \mathrm{l}^{-1}\right)$ & 8.83 & 9.21 & 9.34 & 9.67 & 10.56 & 10.18 & 11.97 & 11.15 \\
\hline $\mathrm{NH}_{4}^{+}\left(\mathrm{mg} \mathrm{l}^{-1}\right)$ & 0.15 & 0.10 & 0.10 & 0.06 & 0.06 & 0.06 & 0.03 & 0.04 \\
\hline $\mathrm{K}^{+}\left(\mathrm{mg} \mathrm{l}^{-1}\right)$ & 1.15 & 1.23 & 1.21 & 1.21 & 1.23 & 1.57 & 1.66 & 1.56 \\
\hline $\mathrm{Ca}^{2+}\left(\mathrm{mg} \mathrm{l}^{-1}\right)$ & 26.46 & 20.00 & 39.18 & 37.90 & 43.21 & 48.01 & 73.07 & 75.09 \\
\hline $\mathrm{F}^{-}\left(\mathrm{mg} \mathrm{l}^{-1}\right)$ & 0.03 & 0.03 & 0.03 & 0.03 & 0.05 & 0.04 & 0.05 & 0.08 \\
\hline $\mathrm{Cl}^{-}\left(\mathrm{mg} \mathrm{l}^{-1}\right)$ & 13.24 & 13.28 & 13.31 & 13.65 & 13.38 & 13.69 & 14.37 & 23.94 \\
\hline $\mathrm{N}-\left(\mathrm{NO}_{2}+\mathrm{NO}_{3}\right)\left(\mathrm{mg} \mathrm{l}^{-1}\right)$ & 3.02 & 2.98 & 3.01 & 2.90 & 2.86 & 2.88 & 3.08 & 0.97 \\
\hline $\mathrm{SO}_{4}^{2-}\left(\mathrm{mg} \mathrm{l}^{-1}\right)$ & 6.09 & 5.50 & 6.22 & 6.11 & 6.32 & 6.33 & 10.25 & 3.53 \\
\hline Soluble Reactive Phosphorus (mg l $\left.\mathrm{m}^{-1}\right)$ & 13.14 & 14.73 & 11.54 & 9.95 & 6.76 & 11.54 & 24.25 & 3.25 \\
\hline Alkalinity $\left(\mathrm{CaCO}_{3} \mathrm{mg} \mathrm{l}^{-1}\right)$ & 230.7 & 224.5 & 226.6 & 245.1 & 224.5 & 226.6 & 230.7 & 234.8 \\
\hline
\end{tabular}




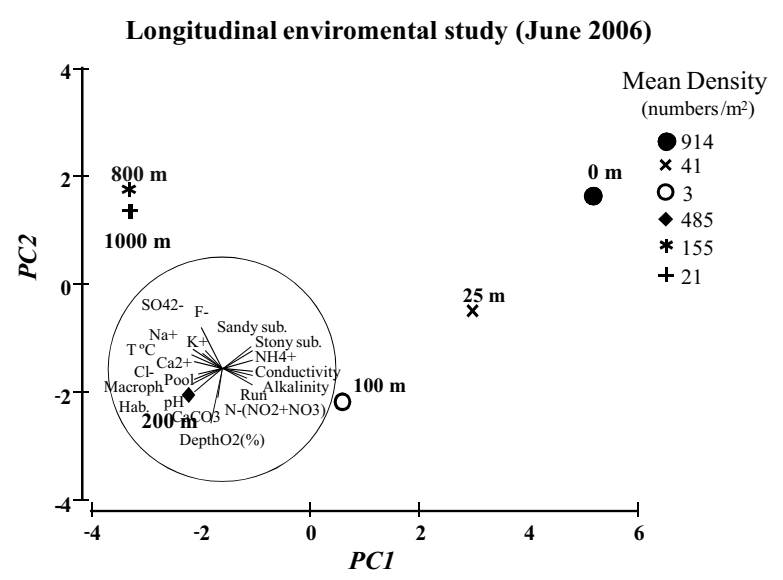

Figure 4. PCA of 10 sites located at increasing distances from the Anços spring, on two consecutive sampling dates $\times$ 21 environmental variables. Axes 1 and 2 explained $63 \%$ and $17 \%$, respectively, of the variation. Data from Table 2. PCA de 10 tramos a distancias crecientes desde el manantial del río Anços, en dos fechas de muestreo consecutivas $\times 21$ variables ambientales. Ejes 1 y 2 explicaron respectivamente $63 \%$ y $17 \%$ de la variación. Datos de la tabla 2.

explained $80 \%$ of the variation $(\mathrm{PCA} 1=63 \%$; PCA2 $=17 \%$; Fig. 4). The PCA biplot did not display the sites in their sequence along the river. The abundances of $T$. fluviatilis were not significantly correlated with any axis (Spearman rank correlation; $p>0.05$ ) or with any measured environmental variable $(p>0.05)$. However, the physical and chemical changes across the stretch studied were very small (Table 2). We were therefore unable to relate the variation in $T$. fluviatilis densities to variations in the abiotic environment.

\section{Population dynamics}

The habitat type and month of the year significantly affected the densities of $T$. fluviatilis. The highest densities were found on stony substrates (2-way ANOVA, $F=1171.219, p<0.001$; date $p<0.009$; habitat $p<0.001$, date $\times$ habitat $p<0.005)$. For stony substrates, the highest densities were observed in August and September (20 000 to 24000 individuals $\mathrm{m}^{-2}$ ) and the lowest densities in December and May ( 3000 individuals $\mathrm{m}^{-2}$ ), but no differences were observed (1-way ANOVA, $F=1.954, p=0.082$, d.f. $=11$; Fig. 5). Floods in October prevented sampling during that month. The biomass varied less than the densities,

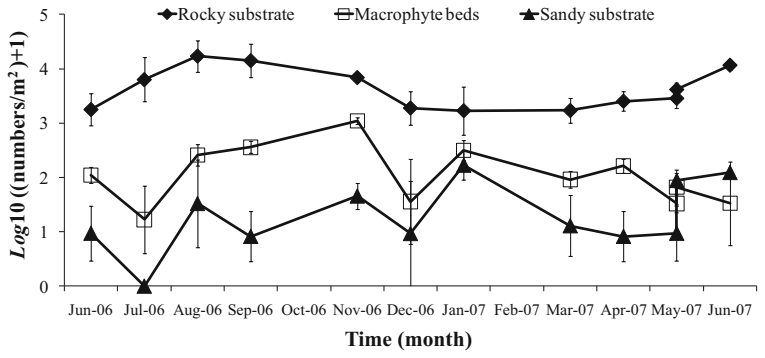

Figure 5. Density of Theodoxus fluviatilis in Anços spring from June 2006 through June 2007 on three substrate types. We sampled twice in May 2007. Mean \pm 1 SE. Densidades de Theodoxus fluviatilis en el manantial del río Anços entre junio de 2006 y junio de 2007 en tres tipos de substrato. En Mayo de 2007 se realizaron dos muestreos. Media \pm 1 SE.

with values generally ranging from 7 to $27 \mathrm{~g}$ AFDM $\mathrm{m}^{-2}$, but the monthly differences were not significant because of high variation and differences in dominant size classes during the year (1-way ANOVA, $F=2.082, p=0.064$, d.f. $=11$; Fig. 6 ).

Egg masses were observed on the substrates during the entire year. Smaller individuals predominated from June through August 2006 and again from May 2007 onwards (Fig. 7); however, small individuals were always present. Taken together, this information suggests continuous reproduction throughout the year. Cohorts were difficult to identify. However, recruitment was likely more intense in summer because peaks of density occurred from July through September 2006 and again in June 2007 and during this period there was a predominance of small individuals. During the year, the overall most abundant size class was $1.13-1.34 \mathrm{~mm}$, the estimated

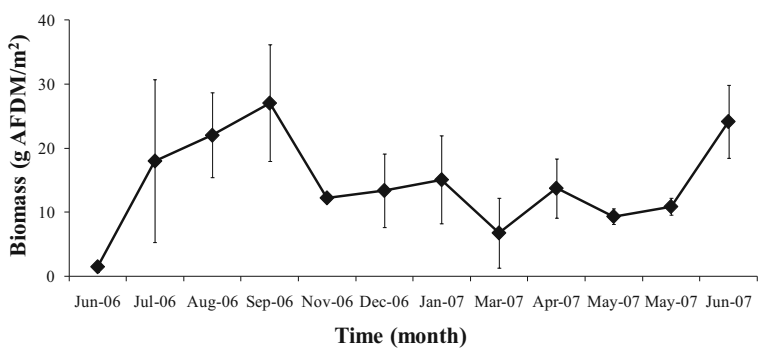

Figure 6. Biomass of Theodoxus fluviatilis in Anços spring from June 2006 through June 2007 on stony substrates. We sampled twice in May 2007. Mean \pm 1 SE. Biomasa de Theodoxus fluviatilis en el manantial del río Anços entre junio de 2006 y junio de 2007 en substratos rocosos En Mayo de 2007 se realizaron dos muestreos. Media $\pm 1 S E$. 

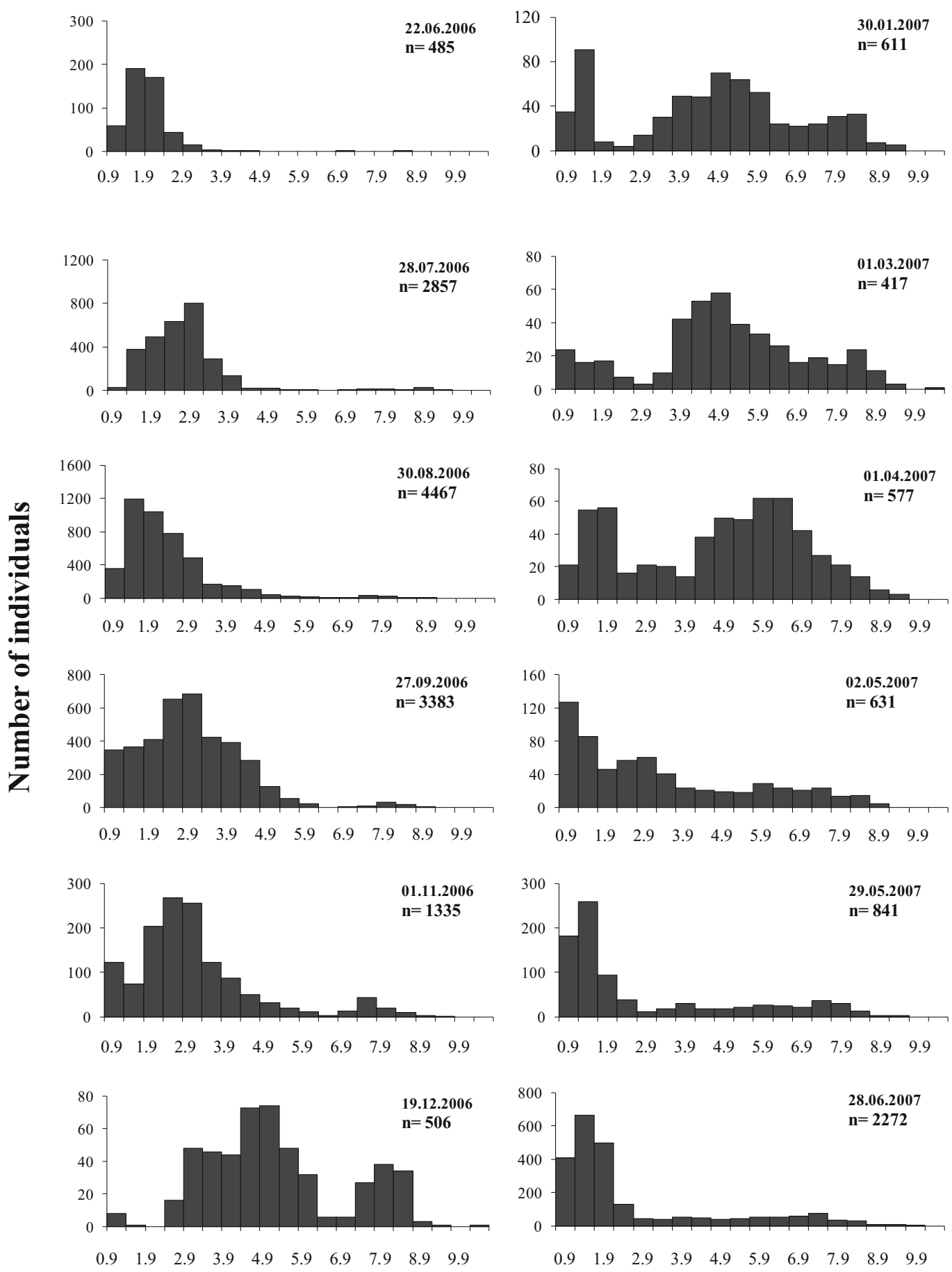

\section{Size classes $(\mathrm{mm})$}

Figure 7. Size-class frequencies of Theodoxus fluviatilis in Anços spring from June 2006 through June 2007. Frecuencia de clases de tamaño de Theodoxus fluviatilis en el manantial del río Anços entre junio de 2006 y julio de 2007. 
Table 3. Estimated Theodoxus fluviatilis population parameters at the Anços spring, using the size frequency method. $\mathrm{P}$ = production; $\mathrm{B}=$ biomass. Parámetros poblacionales estimados para Theodoxus fluviatilis en el manantial del río Anços, de acuerdo con el método de clases de frecuencia. $P=$ producción; $B=$ biomasa.

\begin{tabular}{ll}
\hline Parameters & Values \\
\hline P cohort (hypothetical) & $90.40 \mathrm{~g} \mathrm{AFDM} \mathrm{m}^{-2}$ \\
$\mathrm{P}$ annual & $25.83 \mathrm{~g} \mathrm{AFDM} \mathrm{m}^{-2} \mathrm{year}^{-1}$ \\
Mean B & $15.52 \mathrm{~g} \mathrm{AFDM} \mathrm{m}^{-2}$ \\
$\mathrm{P}$ cohort/Mean B & 5.826 \\
$\mathrm{P}$ annual/Mean B & $1.665 \mathrm{year}^{-1}$ \\
\hline
\end{tabular}

mean biomass was $15.52 \mathrm{~g} \mathrm{AFDM} \mathrm{m}^{-2}$, the annual production was $25.83 \mathrm{~g} \mathrm{AFDM} \mathrm{m}^{-2}$ and the $P / B=1.665$ year $^{-1}$ (Table 3 ). The temperatures at the Anços spring during the study period ranged from 15.3 to $16.6^{\circ} \mathrm{C}$, with minimal daily and yearly variation compared with temperatures recorded $900 \mathrm{~m}$ downstream, where temperatures in the warmest months ranged from 16.0 to $21.4^{\circ} \mathrm{C}$ with maximum daily variations from 3 (shade) to $5^{\circ} \mathrm{C}$ (river exposed to sun; Fig. 8).

\section{DISCUSSION}

T. fluviatilis congregated preferentially on coarse substrates, primarily cobbles and boulders, in shallow areas with a rapid current. Lithophilic congregation was reported previously by other authors (Fertter \& Graham, 1978; Bunje, 2005; Kirkegaard, 2006) and may be related to the greater stability of coarse sediments. Current and substrate particle size are most likely related, with fine particles associated with deposition areas and coarse particles with erosion areas (Giller \& Malmqvist, 1998). Stable and shallow sediments in fast-flowing waters favour the establishment of the periphytic community (Poff et al., 1990; Poff \& Ward, 1992, 1995; Cardinale et al., 2002; Opsahl et al., 2003) where T. fluviatilis feeds. Indeed, this species has been reported as a scraper, feeding mainly on diatoms (Zettler et al., 2004; Kirkegaard, 2006).

We also observed T. fluviatilis associated with macrophytes, as reported previously by Carlsson (2000) and Zettler et al. (2004), and we presume that the reason is the same: substrate for periphyton and high primary productivity. In-

A
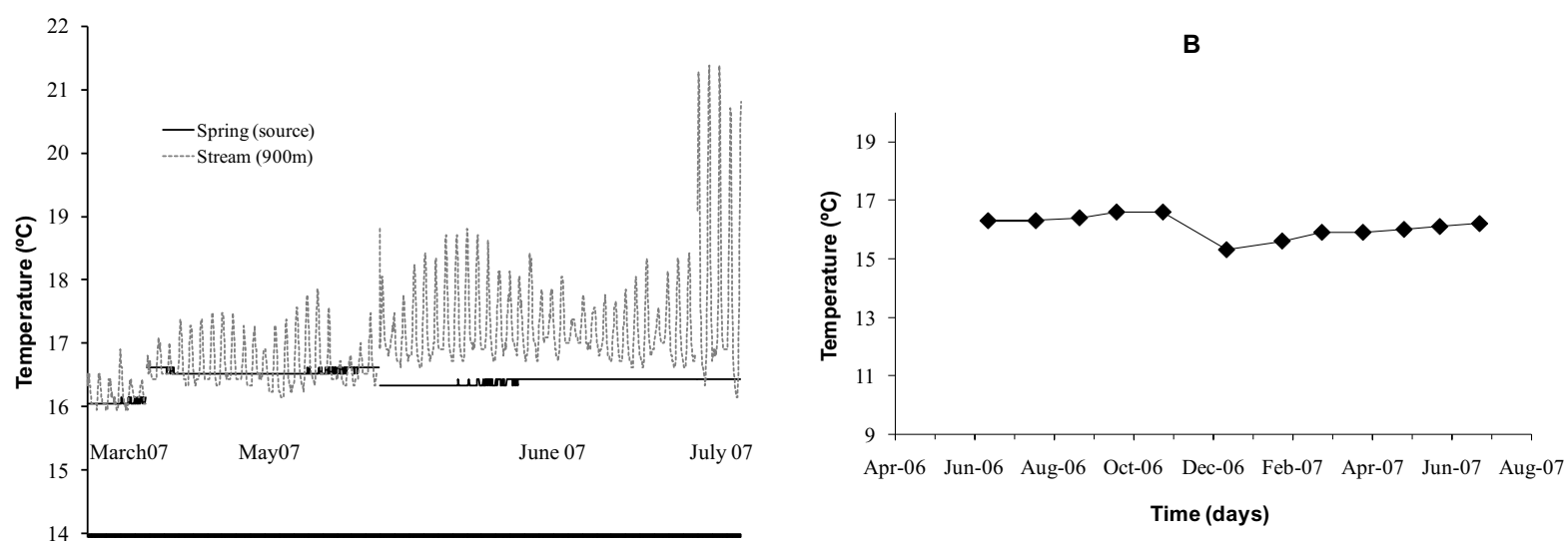

Figure 8. Temperature variation in the waters of Anços spring and $900 \mathrm{~m}$ downstream. A. Hourly measurements on selected days in March, May, June and July 2007. B. Monthly values from June 2006 through June 2007. In the spring, the daily range of variation in March, May and June was $0.09^{\circ} \mathrm{C}$ and in July was $0{ }^{\circ} \mathrm{C} ; 900 \mathrm{~m}$ farther downstream, the range was $1.0,1.0,2.2$ and $2.9^{\circ} \mathrm{C}$, respectively. Variación térmica del agua del manantial del río Anços y 900 m aguas abajo. A. Mediciones realizadas cada hora en días seleccionados en Marzo, Mayo, Junio y Julio de 2007. B. Valores mensuales entre junio 2006 y julio de 2007. En el manantial el rango de las variaciones diarias para marzo, mayo y junio fue de $0.09^{\circ} \mathrm{C}$ y en julio fue de $0{ }^{\circ} \mathrm{C}$; $900 \mathrm{~m}$ rio abajo el rango fue respectivamente $1.0,1.0,2.2$, y $2.9^{\circ} \mathrm{C}$. 
deed, macrophyte production was very high, as judged by the vigorous growth of $A$. nodiflorum. Therefore, the productivity of the periphyton was likely similarly high given the light availability, although this parameter was not measured.

After examining the spatial distribution in the spring, we investigated the longitudinal distribution. We found no strong relationship between any of the measured chemical and physical variables and the numbers of individuals. This lack of relationship was not surprising in terms of water chemistry because the chemical changes were too small to be ecologically relevant. In terms of physical conditions, although sandy substrates were more abundant downstream, stony structures were always present. Moreover, macrophytes (substrates for $T$. fluviatilis) were present along the entire section studied and the numbers of individuals on this substrate decreased farther downstream. These findings are consistent with other studies reporting little change in water chemistry from springs to downstream reaches (e.g., Barquin \& Death 2011).

We should therefore consider other reasons for changes in T. fluviatilis abundance downstream from the karstic spring. One of the explanations could be the stability of conditions in the spring, which would buffer the typical stochasticity of rivers and favour the role of biotic interactions in maintaining the community structure. Therefore, the long-living gastropods could likely outcompete other periphytic consumers, such as baetid mayflies (but not gammarids).

Another explanation for the high abundance of $T$. fluviatilis in the spring, with decreased abundance downstream, could be continuous recruitment in the spring, favoured by constant and favourable temperatures. Temperature is known to control reproductive activity and growth in $T$. fluviatilis (Fretter \& Graham, 1978; Kirkegaard, 2006). Indeed, we found that the temperature was fairly constant at approximately $16^{\circ} \mathrm{C}$, and egg capsules were observed year-round on stones and other snail shells, suggesting continuous reproduction. Moreover, in addition to the direct effect of temperature on $T$. fluviatilis, light availability affects primary production and therefore energy resources for the population. The obser- vation of continuous recruitment contrasts with the pattern reported for populations in a Danish lake, in which the two periods of maximum recruitment that occurred were related to temperature (Kirkegaard, 2006).

The secondary production in the spring was calculated as $25.8 \mathrm{~g} \mathrm{AFDM} \mathrm{m}^{-2}$ year $^{-1}$ and P/B 1.67 year $^{-1}$. The values estimated by Kirkegaard (2006) in a Danish lake were approximately 10fold lower (1.8-2.3 $\mathrm{g} \mathrm{AFDM} \mathrm{m}^{-2}$ year $^{-1}$ ). Our mean density value was 7 -fold higher than that in the Danish site (8300 vs. 1200 individuals $\mathrm{m}^{-2}$ ). These values suggest favourable conditions for $T$. fluviatilis in the Anços spring.

\section{CONCLUSION}

We suggest that the high densities of $T$. fluviatilis in the Anços karstic spring, and presumably in other karstic springs in central Portugal, are the result of high and stable temperatures, which favour continuous reproduction. Lower winter temperatures farther downstream do not eliminate the species but will restrict its reproduction and therefore its densities. The factors affecting the distrition of $T$. fluviatilis will likely affect the distribuution of other species. For example, Echinogammarus meridionalis is another invertebrate occurring in very high numbers in the spring. The abundance of this species decreases downstream (although not as dramatically as T. fluviatilis).

\section{ACKNOWLEDGEMENTS}

This research was financed by the IMAR-CMA. We thank two anonymous reviewers for suggestions and valuable comments on the ms.

\section{REFERENCES}

ALlAN, J. D. \& M. M. CASTILlO. 2007. Stream ecology-structure and function of running waters. Springer. Dordrecht. 445 pp.

APHA. 1995. Standard Methods for the Examination of Water and Watershed. $19^{\text {th }}$ edition. American public health association. Washington DC, USA. 1050 pp. 
BARQUÍN, J. \& R. G. DEATH. 2004. Patterns of invertebrate diversity in streams and freshwater springs in Northern Spain. Archiv für Hydrobiologie, 161: 329-349.

BARQUÍN, J. \& R. G. DEATH. 2006. Spatial patterns of macroinvertebrate diversity in New Zealand springbrooks and rhithral streams. Journal of the North American Benthological Society, 25: 768786.

BARQUÍN, J. \& R. G. DEATH. 2009. Physical and chemical differences in karst springs of Cantabria, northern Spain: do invertebrate communities correspond? Aquatic Ecology. 43:445-455.

BARQUÍN, J. \& R. G. DEATH. 2011. Downstream changes in spring-fed stream invertebrate communities: the effect of increased temperature range? Journal of Limnology, 70 (Suppl. 1): 134-146.

BUNJE, P. M. E. 2005. Pan-European phylogeography of the aquatic snail Theodoxus fluviatilis (Gastropoda: Neritidae). Molecular Ecology, 14: 43234340.

BUNJE, P. M. E. \& D. R. LINDBERG. 2007. Lineage divergence of a freshwater snail clade associated with post-Tethys marine basin development. Molecular Phylogenetics and Evolution, 42: 373387.

CARDINALE, B. J., M. A. PALMER, C. M. SWAN, S. BROOKS \& N. L. POFF. 2002. The influence of substrate heterogeneity on biofilm metabolism in a stream ecosystem. Ecology, 83: 412-422.

CARLSSON, R. 2000. The distribution of the gastropods Theodoxus fluviatilis (L.) and Potamopyrgus antipodarum (Gray) in Lakes on the land Islands, southwestern Finland. Boreal Environment Research, 5: 187-195.

CUNHA, L. 1990. As Serras Calcárias de CondeixaSicó-Alvaiázere-Estudo de Geomorfologia. Instituto Nacional de Investigação Científica, Col. Geografia Física, No. 1. Coimbra. 329 pp.

DAHM, C. N., N. B. GRIMM, P. MARMONIER \& P. VERVIER, 1998. Nutrient dynamics at the interface between surface waters and groundwater. Freshwater Biology, 40: 427-451.
FRETTER, V. \& A. GRAHAM. 1978. The prosobranch molluscs of Britain and Denmark. 3Neriticea, Viviparacea, Valvatacea, terrestrial and freshwater Littorinacea and Rissoacea. Journal of Molluscan Studies Supplement, 5: 101-150.

GILLER, P. \& B. MALMQVIST. 1998. The Biology of Streams and Rivers. Oxford University Press. Oxford. $295 \mathrm{pp}$.

KIRKEGAARD, J. 2006. Life history, growth and production of Theodoxus fluviatilis in Lake Esrom, Denmark. Limnologica, 36: 26-41.

KRUEGER, C. C. \& B. B. MARTIN. 1980. Computation of confidence intervals for the size-frequency (Hynes) method of estimating secondary production. Limnology and Oceanography, 25: 773-777.

NOGUEIRA, A. J. 1992. ANAMOD-Extracção dos Componentes Modais de Distribuições de Frequências de Variáveis Biométricas. Provas de Aptidão Pedagógica e Capacidade Científica. University of Coimbra, Coimbra. 82 pp.

OPSAHL, R., T. WELLNITZ \& N. L. POFF. 2003. Current velocity and invertebrate grazing regulate stream algae results of an in situ electrical exclusion. Hydrobiologia, 499: 135-145.

POFF, N. L., N. J. VOEZ, J. V. WARD \& R. E. LEE. 1990. Algal colonization under four experimentally-controlled current regimes in a high mountain stream. Journal of the North American Benthological Society, 9: 303-318.

POFF, N. L. \& J. V. WARD. 1992. Heterogeneous currents and algal resources mediate in situ foraging activity of a mobile stream graze. Oikos, 65: 465478.

POFF, N. L. \& J. V. WARD. 1995. Herbivory under different flow regimes: a field experimental and test of a model with a benthic stream insect. Oikos, 71:179-188.

ZETTLER, M. L., J. FRANKOWSKI, R. BOCHERT \& M. RÖHNER. 2004. Morphological and ecological features of Theodoxus fluviatilis (Linnaeus, 1758) from Baltic brackish water and German freshwater populations. Journal of Conchology, 38: 305-316. 